\title{
Intracellular pH Regulation in Isolated Rat Bile Duct Epithelial Cells
}

\author{
Mario Strazzabosco, Albert Mennone, and James L. Boyer
}

Department of Internal Medicine and Liver Center, Yale University School of Medicine, New Haven, Connecticut 06510

\begin{abstract}
To evaluate ion transport mechanisms in bile duct epithelium (BDE), BDE cells were isolated from bile duct-ligated rats. After short-term culture pHi was measured with a single cell microfluorimetric set-up using the fluorescent pHi indicator BCECF, and calibrated with nigericin in high $\mathrm{K}^{+}$concentration buffer. Major contaminants were identified using vital markers.

In $\mathrm{HCO}_{3}^{-}$-free media, baseline pHi $(7.03 \pm 0.12)$ decreased by $0.45 \pm 0.18 \mathrm{pH}$ units after $\mathrm{Na}^{+}$removal and by $0.12 \pm .04$ after amiloride administration (1 $\mathrm{mM})$. After acid loading $(20 \mathrm{mM}$ $\left.\mathrm{NH}_{4} \mathrm{Cl}\right)$ pHi recovery was inhibited by both $\mathrm{Na}^{+}$removal and amiloride $\left(\mathrm{JH}^{+}=0.74 \pm 1.1\right.$, and $\mathrm{JH}^{+}=\mathbf{2 . 2 8} \pm \mathbf{0 . 8}$, respectively, vs. $5.47 \pm 1.97$ and $5.97 \pm 1.76 \mathrm{mM} / \mathrm{min}$, in controls, respectively). In $\mathrm{HCO}_{3}^{-}$containing media baseline pHi was higher (7.16 $\pm 0.1, n=36, P<0.05)$ and was decreased by $\mathrm{Na}^{+}$substitution but not by amiloride. $\mathrm{Na}^{+}$removal inhibited $\mathrm{pHi}$ recovery after an intracellular acid load $(0.27 \pm 0.26$, vs. $7.7 \pm 4.1$ $\mathrm{mM} / \mathrm{min}$, in controls), whereas amiloride reduced $\mathrm{JH}^{+}$only by $27 \%$. pH recovery was inhibited by DIDS $(0.5-1 \mathrm{mM})$, but not by $\mathrm{Cl}^{-}$depletion. Finally, acute $\mathrm{Cl}^{-}$removal increased pHi by $0.18 \mathrm{pH}$ units in the absence but not presence of DIDS. These data indicate that $\mathrm{BDE}$ cells possess mechanisms for $\mathrm{Na}^{+} / \mathrm{H}^{+}$ exchange, $\mathrm{Na}^{+}: \mathrm{HCO}_{3}^{-}$symport and $\mathrm{Cl}^{-} / \mathrm{HCO}_{3}^{-}$exchange. Therefore BDE may be capable of transepithelial $\mathrm{H}^{+} / \mathrm{HCO}_{3}^{-}$ transport. (J. Clin. Invest. 1991. 87:1503-1512.) Key words: bile duct epithelial cells $\bullet$ cell isolation and culture $\bullet$ centrifugal elutriation $\bullet$ intracellular $\mathrm{pH}$ regulation $\bullet \mathrm{Na}^{+} / \mathrm{H}^{+}$exchange $\bullet$ $\mathrm{Na}^{+}: \mathrm{HCO}_{3}^{-}$symport $\bullet \mathrm{Cl}^{-} / \mathrm{HCO}_{3}^{-}$exchange $\bullet$ bile secretion $\bullet$ bicarbonate secretion
\end{abstract}

\section{Introduction}

Beginning with small cuboidal cells at the canal of Hering which adjoin the bile canaliculi, the bile duct epithelium $(\mathrm{BDE})^{1}$ branches progressively in columnar fashion ultimately

Part of this work was presented at the American Association for the Study of Liver Diseases meeting, Chicago 1989, and published in abstract form. Hepatology, 1989;10:597.

Dr. Strazzabosco's present address is Istituto di Medicina Interna, Univerita'di Padova, 35100 Padova, Italy.

Address correspondence to James L. Boyer, M.D., LMP 1080, Department of Medicine, 333 Cedar Street, Yale University School of Medicine, New Haven, CT 06510.

Received for publication 6 August 1990 and in revised form 27 November 1990.

1. Abbreviations used in this paper: $\mathrm{BDE}$, bile duct epithelium; $\mathrm{BCECF}$, 2,7-bis(carboxyethyl)-5(6)-carboxy-fluorescein; DiI-Ac-LDL, DiI-conjugated acetyl derivative of low density lipoproteins; GGT, gammaglutamyl transferase; L-15, Leibowitz 15 cell culture medium.

J. Clin. Invest.

(c) The American Society for Clinical Investigation, Inc. $0021-9738 / 91 / 05 / 1503 / 10 \quad \$ 2.00$

Volume 87, May 1991, 1503-1512 forming the extrahepatic and common bile ducts. Although comprising only $3-5 \%$ of the overall population of liver cells (1), this epithelium provides a large surface area for transport between blood and bile and plays a vital anatomical and physiologic role in the elaboration of bile (2). In fact, notwithstanding considerable species variability, studies in the intact animal or perfused liver suggest that bile duct cells have both absorptive and secretory (3-6) capabilities consistent with their intimate relationship to the hepatic artery which forms its vascular supply.

Despite the importance of this epithelium in both the bile secretory process and in acute and chronic cholestatic disorders that comprise the "vanishing bile duct syndrome" (7), little is known regarding the biology and physiology of BDE cells. For example, largely because of the difficulties connected with their isolation, conventional transport techniques have not been used to explore specific transport systems in BDE cells.

To define the mechanisms mediating fluid and electrolyte transport by BDE in greater detail, we have modified recently described procedures for the isolation and short-term culture of BDE cells $(1,8,9)$ and have utilized this preparation to begin characterization of the specific transport mechanisms possibly involved in $\mathrm{H}^{+} / \mathrm{HCO}_{3}^{-}$transport, using the $\mathrm{pH}$-sensitive fluorescent dye BCECF and microfluorimetry of single cells.

\section{Methods}

\section{Materials}

EGTA, penicillin/streptomycin, calf serum, bovine serum albumin, heparin, Hepes, $D(+)$ glucose, insulin, soybean trypsin inhibitor (type (I-S), amiloride, DMSO, deoxyribonuclease (DN-25), nigericin, DIDS, Na-gluconate, K-gluconate, hemicalcium gluconate, and Fast Blue BB salt were purchased from Sigma Chemical Co. (St. Louis, MO). 2,7,bis(carboxyethyl)-5(6)-carboxyfluorescein-acetomethylester (BCECFAM) was obtained from Molecular Probes, Inc. (Eugene, OR). Percoll was obtained from Pharmacia Fine Chemicals (Piscataway, NJ), Matrigel TM from Collaborative Research, Inc. (Bedford, MA), Collagenase A from Boehringer Mannheim Biochemicals (Indianapolis, IN) and Pronase from Calbiochem-Behring Corp. (La Jolla, CA). Liebowitz 15 (L 15), MEM, Joklik modified MEM, $\alpha$-MEM, L-glutamine, gentamicin, and FCS were from Gibco Laboratories (Grand Island, NY). Acetylated LDL labeled with 1,1-dioctadecyl-1-1,3,3,3',3'-tetramethylindo-carbocyanine perchlorate (DiI) were from BioTechnology Inc. (Stoughton, MA). N(gamma-1-glutamyl)-4-methoxy-2-napthylamide was obtained from Polyscience, Inc. (Warrington, PA). Monoclonal anticytokeratin 7 and 19 antibodies (RPN 1162 and RPN 1165, respectively) were purchased from Amersham Corp. (Arlington Heights, IL), whereas monoclonal antibody anti-rat-leukocyte-common-antigen, clone MCR OX1, was from Serotec, Inc. (Oxford, UK), and Cell-Tak from BioPolymers, Inc. (Farmington, CT).

\section{Bile ductular cell isolation}

Bile duct epithelial cells were isolated from 230-250-g male SpragueDawley rats (Camm Research Laboratories) 3-5 wk after bile duct ligation, by a modification of the method of Mathis et al. (8). Modifications involved further purification by centrifugal elutriation and selective adherence of Kupffer cells and inflammatory cells to plastic. In 
addition, animals received alternate day s.c. injections of $3 \mathrm{mg}$ phytonadione (AquaMephyton, MSD, West Point, PA) to prevent hemorrhage. Briefly, the portal tissue obtained after collagenase digestion of the liver and containing the hyperplastic bile duct epithelium was separated mechanically from parenchymal tissue, finely minced and further digested with collagenase, hyaluronidase, and DNase. The obtained crude nonparenchymal cell suspension was then subjected to a double Percoll density gradient centrifugation and viable cells banding at densities $1.060-1.075$ were collected.

The pellet was resuspended in $50 \mathrm{ml}$ Joklik modified MEM and then subjected to centrifugal elutriation with a model JE-6B elutriator (Beckman Instruments, Inc., Palo Alto, CA) Ice cold MEM supplemented with $0.004 \%$ DNase, $10 \%$ calf serum, penicillin/streptomycine, and L-glutamine was used as elutriation medium and the rotor speed was set as $2,500 \mathrm{rpm}$. Cells were loaded at a flow rate of $9 \mathrm{ml} / \mathrm{min}$. Thereafter $150-\mathrm{ml}$ aliquots were collected while sequentially increasing the flow rate to $16,24,30,38$ and $46 \mathrm{ml} / \mathrm{min}$. All fractions were then pelleted and resuspended in $\mathrm{L}-15$ medium containing insulin $(0.1 \mu \mathrm{M})$, FCS (3\%), L-glutamine ( $2 \mathrm{mM})$, Hepes $(25 \mathrm{mM})$, gentamicin $(50 \mu \mathrm{g} /$ $\mathrm{ml})$, penicillin/streptomycin $(100,000 \mathrm{U}-100 \mathrm{mg} /$ liter) (plating medium).

Fraction 30 and 38 were combined into plastic tissue culture flasks (Falcon Plastics, Cockeysville, MD) and cells were allowed to settle and adhere to the plastic for $1 \mathrm{~h}$ at $37^{\circ} \mathrm{C}$. Nonadherent cells were resuspended by swirling the flasks gently, pelleted, and again resuspended in plating medium. Aliquots were taken for determination of cell viability, yield, and cyto- or immunocytochemistry. The remaining cells were plated at a density of $4 \times 10^{3} \mathrm{cell} / \mathrm{mm}^{2}$ in L-15 medium into tissue culture plastic wells (Corning Glass Works, Corning, NY) containing glass coverslip fragments coated with a thin layer of EHS matrix (Matrigel TM, Collaborative Research, Inc.) at $37^{\circ} \mathrm{C}$ in an air equilibrated incubator. Medium was changed after $4 \mathrm{~h}$. Preparations used to study pHi regulation were cultured in these conditions for 6-24 h. In experiments performed in the presence of bicarbonate, medium was changed after $4 \mathrm{~h}$ to $\alpha$-MEM containing the same additives, but $25 \mathrm{mM}$ $\mathrm{NaHCO}_{3}$ replaced $25 \mathrm{mM}$ Hepes.

\section{Cell identification}

Viability, counting and sizing. Viability was determined by Trypan blue exclusion. Cells were counted and sized with a Channalizer 256 counter Coulter Electronics, Inc., Hialeah, FL.

Gammaglutamyl-transpeptidase (GGT). Freshly isolated cells (plated on Cell-Tak coated coverslips for $30 \mathrm{~min}$ at $37^{\circ} \mathrm{C}$ ) and cells cultured for 15-24 h on Matrigel coated coverslip fragments were then fixed in cold acetone for $10 \mathrm{~min}$. GGT cytochemistry was performed as described $(10,11)$.

Endogenous peroxidase activity. Cells were plated on Cell-Tak, fixed in $4 \%$ paraformaldehyde, preincubated in diaminobenzadine (DAB) $(0.1 \%)$ and then reacted with $0.01 \% \mathrm{H}_{2} \mathrm{O}_{2}$ for $15 \mathrm{~min}$.

Cytokeratin immunocytochemistry. Cells were plated and fixed as described for GGT. After preincubation for $30 \mathrm{~min}$ in $10 \%$ normal goat serum, primary monoclonal antibodies (anti-cytokeratin 19 and 7) were then added (1:10 and 1:30, respectively) with $0.1 \mathrm{M}$ PBS and $0.05 \%$ saponin. After incubation for $1 \mathrm{~h}$ at room temperature, secondary antibody (anti-mouse IgG FITC conjugated) was added ( $1: 200)$ for $1 \mathrm{~h}$ at room temperature in the same buffer. When an immunoperoxidase technique was employed, 1:100 Fab anti-mouse peroxidase-conjugated antibody was used as a secondary antibody. Thereafter, the specimens were treated as described for peroxidase cytochemistry.

Leukocyte common antigen. Freshly isolated cells were incubated for $1 \mathrm{~h}$ with 1:100 monoclonal mouse anti-rat common antigen (12) in ice-cold PBS. Slides were then reacted with FITC-conjugated secondary goat anti-mouse IgG (1:200) for $30 \mathrm{~min}$, washed, and mounted.

Vital markers. Vital markers for endothelial cells and Kupffer cells were also used to identify these contaminants directly on the stage of the microscope before selecting the cells to be studied. Acetylated LDL labeled with the fluorescent dye Dil was used to label endothelial cells and macrophages $(13,14)$ by incubating the plated cells for $3-4 \mathrm{~h}$ in
L-15 medium containing $10 \mu \mathrm{g} / \mathrm{ml}$ Ac-Dil-LDL. Colloidal ink phagocytosis was demonstrated by administering Higgins India ink to the rat via the inferior vena cava 10 min before liver perfusion, at the dose of 9 $\mathrm{mg}(13,15)$.

Electron microscopy. In selected experiments, freshly isolated cells and cells maintained in culture for $6 \mathrm{~h}$ were processed for electron microscopy as previously described for hepatocytes (16).

\section{pHi determination}

Intracellular $p H i$. This was measured using the fluorescent $\mathrm{pHi}$ indicator, BCECF given as the acetoxymethyl-ester. Because the yield of cells was low and the preparation contained contaminants, a microfluorimetric, single-cell method was employed (17).

Optical system. Bile duct cells on glass coverslips were loaded with BCECF $(12 \mu \mathrm{M})$ for 30-40 min, washed for $10 \mathrm{~min}$ in BCECF-free medium, and transferred onto a thermostated perfusion chamber placed on the stage of a Zeiss IM 35 inverted microscope. Proper gassing of the various perfusion media (see Table I) was facilitated by an artificial lung. pHi was measured as the ratio between the pHi-sensitive and the isosbestic excitation wavelengths $(495 / 440 \mathrm{~nm})$. In preliminary experiments wavelengths were changed by rapid manual displacements. Subsequently the microscope was connected to a Spex-AR-CMmicro system (Spex Industries, Edison, NJ) equipped with a rotating chopper mirror able to rapidly alternate the light generated by a $150-\mathrm{W}$ xenon lamp between two excitation beams. A pinhole device (Nikon) was inserted in the emission light pathway to restrict the measuring spot of the photometer to a selected area of the field. The emitted light was read at $530 \mathrm{~nm}$ by a photometer with a photon-counting attachment. Background fluorescence was then determined, measuring a cell-free area of the same size (18) and substracted from fluorescent intensity readings. Average signal to background ratio was 77:1.

Cell identification and selection. Clusters of at least 5-10 small (9$13 \mu \mathrm{m}$ diameter) mononucleated cells were selected for study (9). Cells were avoided if they contained colloidal carbon particles (Kupffer cells) $(13,15)$, showed a fibroblastlike aspect, or contained cytoplasmic translucent vacuoles (Ito cells) (19). Endothelial cells and macrophages which take up DiI-Ac-LDL were also excluded (13-15).

pHi calibration. 495/490 F1 ratio data were converted to $\mathrm{pHi}$ values by generating a calibration curve at the end of each experiment. Cells were exposed to nigericin $(24 \mu \mathrm{M})$ in a $\mathrm{Na}^{+}$-free medium contain-

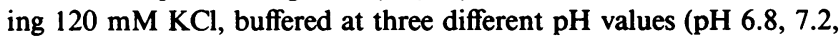
$7.6)$, as previously described $(20,21)$.

Determination of total $\left(\beta_{t o o}\right)$ and intrinsic $\left(\beta_{i}\right)$ intracellular buffering power. The intrinsic buffering power $\left(\beta_{i}\right)$ (in the absence of the open buffering system $\mathrm{HCO}_{3}-\mathrm{CO}_{2}$ ) was determined at different $\mathrm{pHi}$ as recently described $(n=7)(18,22)$. The total intracellular buffering power (in the presence of bicarbonate) $\beta_{10 \mathrm{t}}$, was then calculated from $\beta_{\mathrm{i}}$ as: $\beta_{\text {tot }}$ $=\beta_{\mathrm{i}}+2.302 \times\left[\mathrm{HCO}_{3}^{-}\right]_{\mathrm{i}}$ (where $\left[\mathrm{HCO}_{3}^{-}\right]_{1}$ is derived from the Henderson-Hasselbach equation). Transmembrane $\mathrm{H}^{+}$fluxes $\left(\mathrm{JH}^{+}\right)$were calculated from $\delta \mathrm{pHi} / \delta t$ as $\mathrm{JH}^{+}=\beta_{\mathrm{i}} \times \delta \mathrm{pHi} / \delta t$, where the $\delta \mathrm{pHi} / \delta t$ was measured by hand-drawn tangent from the experimental plots.

\section{Solutions}

The composition of solutions used for studies on $\mathrm{pHi}$ regulation are given in Table I. A $1 \mathrm{mM}$ stock solution of BCECF was solubilized in DMSO, whereas amiloride was dissolved by gently warming in deionized water.

\section{Statistical analysis}

Data are presented as arithmetical means \pm SD, unless otherwise stated. Statistical analysis were conducted using the paired or unpaired $t$ test, as appropriate.

\section{Results}

\section{Bile duct epithelial cell isolation and culture}

An average of $5.7 \pm 2 \times 10^{6}$ nonadherent cells with a median diameter of $10.5 \mu \mathrm{m}$ and a viability of $89 \pm 3 \%$ were recovered 
Table I. Composition of Buffer Solutions Used

\begin{tabular}{|c|c|c|c|c|c|c|c|}
\hline & Hepes & $\begin{array}{l}\text { Hepes } \\
0 \mathrm{Na}^{+}\end{array}$ & $\begin{array}{c}\text { Hepes } \\
\mathrm{NH}_{4}\end{array}$ & KRB & $\begin{array}{c}\mathrm{KRB} \\
\mathbf{0 \mathrm { Na } ^ { + }}\end{array}$ & $\begin{array}{l}\mathrm{KRB} \\
0 \mathrm{Cl}^{-}\end{array}$ & $\begin{array}{l}\mathrm{KRB} \\
\mathrm{NH}_{4}\end{array}$ \\
\hline & $m M$ & $m M$ & $m M$ & $m M$ & $m M$ & $m M$ & $m M$ \\
\hline $\mathrm{Na}^{+}$ & 141 & 0 & 121 & 140 & 0 & 140 & 110 \\
\hline $\mathrm{K}^{+}$ & 5.9 & 5.9 & 5.9 & 5.9 & $5: 9$ & 5.9 & 5.9 \\
\hline $\mathrm{Mg}^{+}$ & 1 & 1 & 1 & 1 & 1 & 1 & 1 \\
\hline $\mathrm{Ca}^{2+}$ & 1.25 & 1.25 & 1.25 & 1.25 & 1.25 & 1.25 & 1.25 \\
\hline Choline & 0 & 135 & 0 & 0 & 140 & 0 & 0 \\
\hline TMA & 0 & 6 & 0 & 0 & 0 & 0 & 0 \\
\hline $\mathrm{Cl}^{-}$ & 142.2 & 142.2 & 142.2 & 122.2 & 122.2 & 0 & 122.2 \\
\hline $\mathrm{SO}_{4}^{-}$ & 1 & 1 & 1 & 1 & 1 & 1 & 1 \\
\hline $\mathrm{PO}_{4}^{-}$ & 1.2 & 1.2 & 1.2 & 1.2 & 1.2 & 1.2 & 1.2 \\
\hline $\mathrm{HCO}_{3}^{-}$ & 0 & 0 & 0 & 25 & 25 & 25 & 25 \\
\hline Hepes & 10 & 10 & 10 & 0 & 0 & 0 & 0 \\
\hline Gluconate & 0 & 0 & 0 & 0 & 0 & 123.5 & 0 \\
\hline $\mathrm{NH}_{4}^{+}$ & 0 & 0 & 20 & 0 & 0 & 0 & 30 \\
\hline Glucose & 5.5 & 5.5 & 5.5 & 5.5 & 5.5 & 5.5 & 5.5 \\
\hline Pyruvate & 1 & 0 & 0 & 1 & 0 & 1 & 0 \\
\hline $\mathrm{O}_{2}(\%)$ & 100 & 100 & 100 & 95 & 95 & 95 & 95 \\
\hline $\mathrm{CO}_{2}(\%)$ & 0 & 0 & 0 & 5 & 5 & 5 & 5 \\
\hline pH & 7.4 & 7.4 & 7.4 & 7.4 & 7.4 & 7.4 & 7.4 \\
\hline
\end{tabular}

from the combined fractions 30 and $38(n=25)$. The majority of the cells stained positively for GGT $(72 \pm 7.2 \%$, range 60 $85 \%)$ and were therefore identified as BDE cells (Fig. $1 C)(1,2$, $8,9,23)$. BDE cells were also positive for CK $19+7(62 \pm 8 \%)$ Fig. $1, A$ and $B(1,2,9)$. Dil and peroxidase positive cells (endothelial cells, macrophages, and Kupffer cells) were 13.4 \pm 3.7 and $12 \pm 6.5 \%$, respectively. LCA positive cells were $3 \pm 0.4 \%$. Contamination with hepatocytes was minimal.

BDE cells easily attached to Matrigel, when plated at relatively high density in L-15 medium supplemented with $3 \%$ FCS (10). Moreover, the percentage of GGT-positive cells increased by $8-10 \%$ after $15-24 \mathrm{~h}$ culture suggesting that the biomatrix favored attachment of BDE cells compared to contaminants. Cultured BDE cells appeared as small (8-13 $\mu \mathrm{m})$ mononucleated rounded cells mostly organized in three-dimensional clusters rather than in monolayers (8). Fig. $1 D$ illustrates a cluster of BDE cells, $6 \mathrm{~h}$ after plating demonstrating preservation of cell ultrastructure and reestablishment of tight contacts between the cells. These cells were clearly distinguishable from occasional contaminants like hepatocytes, cells with fibroblastoid appearance and from very flattened cells with cytoplasmic refractile vacuoles, that were identified as Ito cells (19). Because clusters were mostly GGT-positive, cluster formation was also used as a criteria when selecting cells for functional studies.

Cells that phagocytosed colloidal ink ( $3 \%$ of the cell population) were easily distinguishable because of the presence of black cytoplasmic inclusions. However, in BDL rats, identification of Kupffer cells by colloidal ink was less effective than in normal rats, because the percent of ink positive cells was significantly lower than that of peroxidase positive cells presumably reflecting impairment of the reticuloendothelial system in the liver during cholestasis. DiI-Ac-LDL-positive cells (endothelial cells and macrophages) could also be easily identified on the stage of the microscope because of their bright fluorescence under rhodamine excitation.

\section{pHi regulation in $B D E$ cells}

$B C E C F$ loading. BDE cells required a 30-40-min incubation in BCECF to load in contrast to hepatocytes where 3-5 min would be sufficient to give strong fluorescent signals. This finding is consistent with a deficiency of phase I reaction enzymes in BDE (23). On the other hand, dye leakage was not a significant problem in BDE cells, and fluorescent signals could be obtained from the same cells for up to $40 \mathrm{~min}$.

Intrinsic buffering power. $\beta$ i measured $27.6 \mathrm{mM} / \mathrm{pH}$ unit at pHi 6.85 , in agreement with values reported for many cells, including rat hepatocytes in subconfluent monolayers (21). When measured at different $\mathrm{pHi}, \beta \mathrm{i}$ changed from $17.88 \mathrm{mM} /$ $\mathrm{pH}$ unit at pHi 7 to $65.64 \mathrm{mM} / \mathrm{pH}$ unit at $\mathrm{pHi} 6.55$. A similar strong dependency of $\beta \mathrm{i}$ on $\mathrm{pHi}$ has also been demonstrated in mesangial (18), hepatoma (22), parietal cells (24), and hepatocytes (25).

pHi regulation in bicarbonate-free media: basal pHi. Basal pHi in a nominally bicarbonate-free Hepes-buffered medium, measured 7.03 $\pm 0.12(n=14)$. As shown in Fig. 2 when external $\mathrm{Na}^{+}$was removed by substitution with choline (maneuver that reverses the mode of operation of the $\mathrm{Na}^{+} / \mathrm{H}^{+}$exchanger), pHi decreased by $0.45 \pm 0.18(n=4) \mathrm{pHi}$ units at a rate of $-11.6 \pm 2.54 \mathrm{mM} / \mathrm{min}$. After $\mathrm{Na}^{+}$readmission, $\mathrm{pHi}$ rapidly recovered to baseline. Amiloride $(1 \mathrm{mM}), \mathrm{a} \mathrm{Na}^{+} / \mathrm{H}^{+}$exchange inhibitor also produced a reversible fall in $\mathrm{pHi}(0.12 \pm 0.04 \mathrm{pH}$ units, $n=4$ ) at a rate of $-2.14 \mathrm{mM} / \mathrm{min}$. This data indicates that the steady-state pHi of BDE cells, in the absence of $\mathrm{HCO}_{3}^{-}$ is maintained by $\mathrm{Na}^{+}$-dependent, amiloride-inhibitable mechanism (likely a $\mathrm{Na}^{+} / \mathrm{H}^{+}$exchange).

Recovery of $p H$ i from an acute acid load. To study transport mechanisms that mediate $\mathrm{H}^{+}$extrusion in BDE cells, we evaluated the recovery of pHi after an acute acid load with $20 \mathrm{mM}$ $\mathrm{NH}_{4} \mathrm{Cl}$ as described $(21,26)$. As shown in Fig. $3 A$, BDE cells recover from the acid load (nadir pHi $6.70 \pm 0.13, n=14$ ) by extruding protons at a maximal rate of $7.45 \pm 2.66 \mathrm{mM} / \mathrm{min}(n$ $=14)($ or $5.76 \pm 1.78 \mathrm{mM} / \mathrm{min}(n=14)$ at $\mathrm{pHi}=6.78 \pm 0.09)$. 

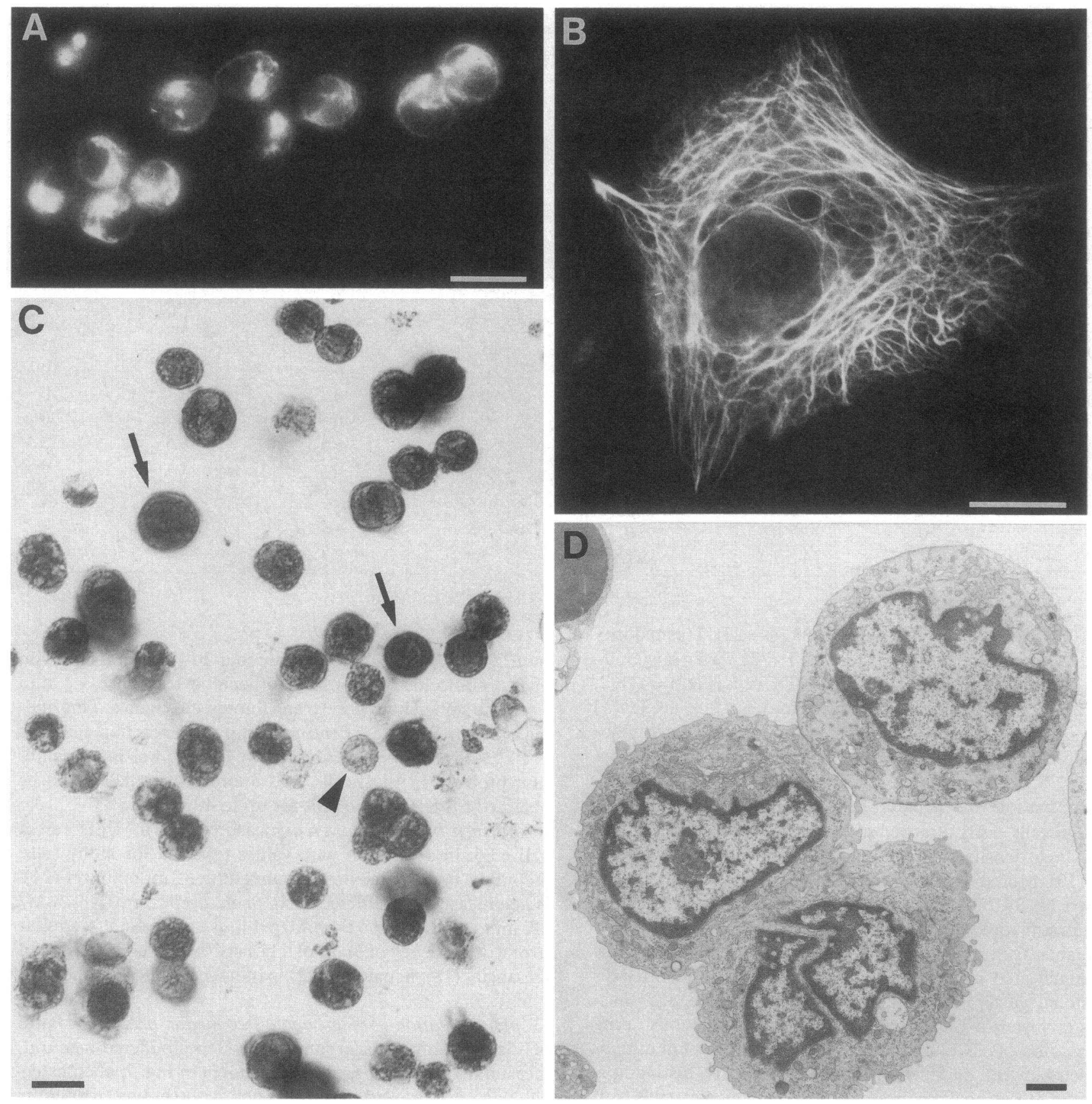

Figure 1. (A) Group of freshly isolated BDE cells from fractions 30 and 38 combined showing positive immunocytochemical staining for cytokeratin $19+7$. Magnification, 1,213. Bar, $10 \mu \mathrm{m}$. (B) Cytokeratin $19+7$ immunocytochemistry of a BDE cell cultured for $6 \mathrm{~d}$ on matrigel. Magnification, 1,535. Bar, $10 \mu \mathrm{m}$. $(C)$ Freshly isolated BDE preparation from fractions 30 and 38 combined. GGT cytochemistry. Original magnification, 848. Bar, $10 \mu \mathrm{m}$. (D) Electron microscopy of BDE cells after $6 \mathrm{~h}$ culture on matrigel. Horizontal section through a cluster of cells. Note interdigitating intercellular spaces and the presence of tight contacts between the cells with desmosomes. Magnification, 6,125. Bar, 1.0 $\mu \mathrm{m}$.

In six experiments, a second $\mathrm{NH}_{4} \mathrm{Cl}$ pulse was performed and, at the moment of $\mathrm{NH}_{4} \mathrm{Cl}$ withdrawal, external $\mathrm{Na}^{+}$was completely substituted with choline (Fig. $3 A$ ). After $\mathrm{Na}^{+}$removal, intracellular acidification was much greater (nadir pHi reaching $6.5 \pm 0.2$ ) and $\mathrm{pHi}$ recovery was completely blocked $\left(\mathrm{JH}^{+}=0.74 \pm 1.12 \mathrm{mM} / \mathrm{min}\right)$. $\mathrm{pHi}$ rapidly returned to basal values after $\mathrm{Na}^{+}$readmission.

Moreover, when BDE cells were superfused with $1 \mathrm{mM}$ amiloride after withdrawal of $\mathrm{NH}_{4} \mathrm{Cl},(n=8$, Fig. $3 \mathrm{~B})$, pHi recovery was greatly slowed $\left(\mathrm{JH}^{+}=2.28 \pm 0.8 \mathrm{mM} / \mathrm{min}\right.$ and $0.03 \pm 0.01 \delta \mathrm{pHi} / \mathrm{min}$ during amiloride vs. $5.97 \pm 1.76 \mathrm{mM} / \mathrm{min}$ and $0.16 \pm 0.06 \delta \mathrm{pHi} / \mathrm{min}$ during control pulses). Inhibition was reversible and $\mathrm{pHi}$ recovered to baseline after withdrawal of amiloride.

Although $38 \%$ of $\mathrm{H}^{+}$efflux was insensitive to amiloride inhibition, these data are most consistent with the experiments on basal $\mathrm{pHi}$ and suggest that in nominally $\mathrm{HCO}_{3}^{-}$-free medium, BDE cells recover from an acute acid load primarily by 


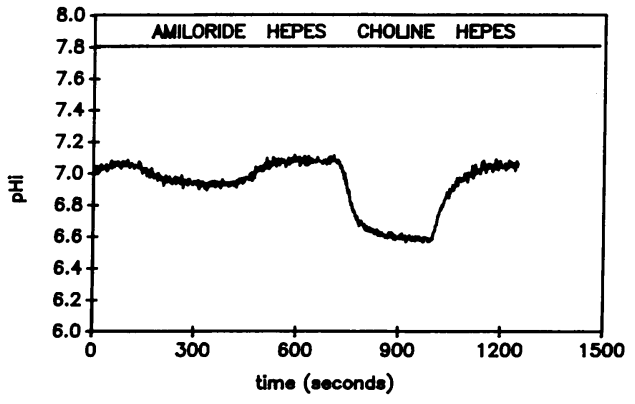

Figure 2. Effects of amiloride and sodium removal on baseline $\mathrm{pH}$ in isolated BDE cells. BDE cells were loaded with BCECF for 30 min and washed for $10 \mathrm{~min}$. The tracing shows the fluorescence intensity ratio, calibrated as pHi, recorded from a cluster of 5-10 BDE cells. Solutions were changed as indicated above the trace. Cells, bathed in $\mathrm{HCO}_{3}^{-}$-free Hepes-buffered Ringers, were first perfused with the $\mathrm{Na}^{+} / \mathrm{H}^{+}$inhibitor, amiloride $(1 \mathrm{mM})$. pHi decreased and then returned to baseline after amiloride washout. pHi rapidly acidified also after external $\mathrm{Na}^{+}$substitution (choline) and rapidly returned to baseline after $\mathrm{Na}^{+}$readmission. The tracing is a representative example of four similar experiments.
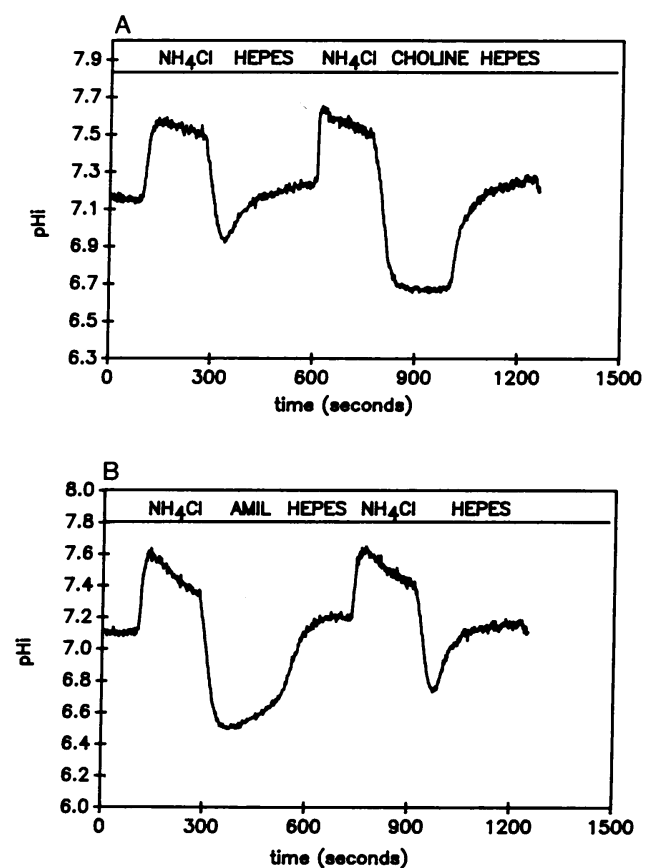

Figure 3. (A) Effects of external $\mathrm{Na}^{+}$removal on pHi recovery from an acid load induced by pulse withdrawal of $20 \mathrm{mM} \mathrm{NH}_{4} \mathrm{Cl}$ in the nominal absence of $\mathrm{HCO}_{3}^{-}$. pHi changes during two different pulses are shown. pHi rises upon exposure to $\mathrm{NH}_{4} \mathrm{Cl}$ due to the entry of the permeant weak base $\mathrm{NH}_{3}$ and its protonation to the impermeant $\mathrm{NH}_{4}^{+}$. After withdrawal of external $\mathrm{NH}_{4} \mathrm{Cl}, \mathrm{NH}_{4}^{+}$releases a proton and leaves the cell as $\mathrm{NH}_{3}$, thereby acutely acidifying the cell. BDE cells rapidly recover to baseline in normal Hepes-buffered Ringer media. When the acid load is performed in $\mathrm{Na}^{+}$-free Ringer's (second pulse), nadir pHi is more acid and pHi recovery is completely blocked until $\mathrm{Na}^{+}$is readmitted. The tracing is representative of six similar experiments. $(B)$ Effects of the $\mathrm{Na}^{+} / \mathrm{H}^{+}$exchange inhibitor amiloride on $\mathrm{pHi}$ recovery from an acid load in the absence of $\mathrm{HCO}_{3}^{-}$. $\mathrm{BDE}$ cells were acidified as described above. When amiloride was present (first pulse) pHi recovery was greatly inhibited compared to control pulses (second part of the tracing). Data are representative of eight similar experiments.

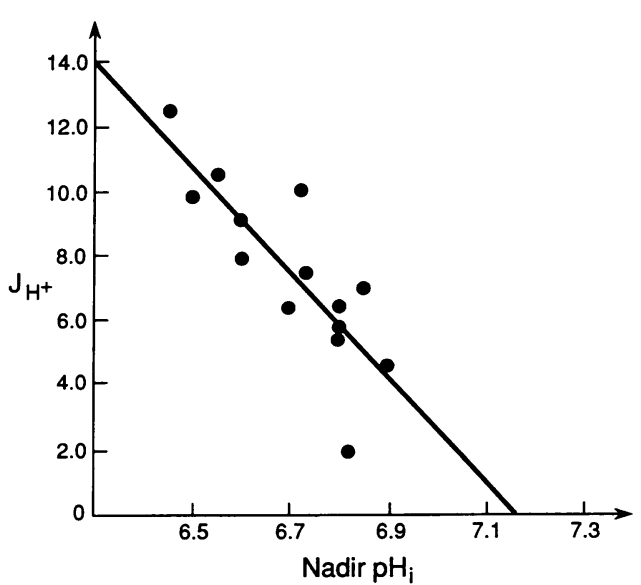

Figure 4. Relationship between maximal $\mathrm{H}^{+}$efflux rates $\left(\mathrm{JH}^{+}\right)$and pHi after $\mathrm{NH}_{4} \mathrm{Cl}$ pulse. In $\mathrm{HCO}_{3}^{-}$-free medium, $\mathrm{JH}^{+}$is presumed to reflect $\mathrm{Na}^{+} / \mathrm{H}^{+}$exchange activity. $\mathrm{JH}_{\max }^{+}$was calculated as described in the methods section, from $\beta \mathrm{i}$ and maximal recovery rates.

$\mathrm{Na}^{+} / \mathrm{H}^{+}$exchange. Moreover, when maximal acid extrusion rates were plotted versus nadir pHi (Fig. 4) an inverse relationship between these two parameters was found $(r=0.83, y$ $=1.17-1.64 x$ ) consistent with activation of $\mathrm{BDE}$ cell Na $\mathrm{Na}^{+} / \mathrm{H}^{+}$ exchange by intracellular acidification, as described for a number of other cell types (27).

pHi regulation in the presence of bicarbonate: basal pHi. In the presence of $25 \mathrm{mM} \mathrm{HCO}_{3}^{-} / 5 \% \mathrm{CO}_{2}$, basal pHi of BDE cells was significantly higher than in the absence of bicarbonate $(7.16 \pm 0.11$ vs. $7.03 \pm 0.12, P<0.05, n=36)$. In four experiments acute $\mathrm{Na}^{+}$removal with choline decreased pHi by $0.52 \pm 0.2 \mathrm{pHU}$, whereas amiloride had no effect on baseline pHi, when $\mathrm{HCO}_{3}^{-}$was present (Fig. 5). However, after incubation with $0.5 \mathrm{mM}$ DIDS, an inhibitor of $\mathrm{HCO}_{3}^{-}$-dependent transport processes (Table II), pHi was significantly reduced to $6.95 \pm 0.09$, a value not significantly different from baseline $\mathrm{pH}$ in Hepes buffer. These data suggest that a $\mathrm{Na}^{+}$-dependent amiloride-insensitive, DIDS-inhibitable $\mathrm{HCO}_{3}^{-}$transport mechanism maintains pHi above the one measured in bicarbonatefree media.

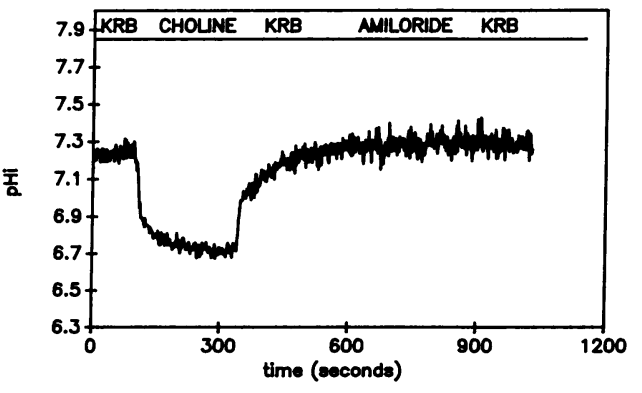

Figure 5. Effect of external $\mathrm{Na}^{+}$removal and amiloride on baseline pHi in the presence of $\mathrm{HCO}_{3}^{-}$. BDE cells, bathed in $\mathrm{KRB}$, gassed with $95 \% \mathrm{O}_{2} / 5 \% \mathrm{CO}_{2}$, rapidly acidified when exposed to a $\mathrm{Na}^{+}$-free KRB (equimolar substitution with choline). pHi rapidly recovered to baseline when $\mathrm{Na}^{+}$was readmitted. On the other hand, amiloride $(1 \mathrm{mM})$ had no effect on baseline pHi. Data are representative of four similar experiments. 
Table II. pHi Recovery from Acute Intracellular Acid Load

\begin{tabular}{|c|c|c|c|}
\hline Condition & Basal pHi & Recovery rates & $\mathrm{JH}^{+}$ \\
\hline & pHi units & $\delta p H i / m i n$ & $\mathrm{mM} / \mathrm{min}$ \\
\hline $\begin{array}{l}\text { Hepes controls } \\
\quad(n=6)\end{array}$ & $7.05 \pm 0.12$ & $0.14 \pm 0.04$ & $5.47 \pm 1.97$ \\
\hline $\begin{array}{l}\text { Hepes Na-free } \\
\quad(n=6)\end{array}$ & $7.04 \pm 0.15$ & $0.01 \pm 0.016$ & $0.74 \pm 1.12$ \\
\hline $\begin{array}{l}\text { Hepes controls } \\
\quad(n=8)\end{array}$ & $7.01 \pm 0.12$ & $0.16 \pm 0.06$ & $5.97 \pm 1.76$ \\
\hline $\begin{array}{l}\text { Hepes amiloride } \\
\quad(n=8)\end{array}$ & $7.00 \pm 0.13$ & $0.03 \pm 0.01$ & $2.28 \pm 0.8$ \\
\hline $\begin{array}{l}\text { KRB controls } \\
(n=6)\end{array}$ & $7.08 \pm 0.01$ & $0.14 \pm 0.05$ & $7.77 \pm 4.1$ \\
\hline $\begin{array}{l}\text { KRB Na-free } \\
\quad(n=6)\end{array}$ & $7.07 \pm 0.11$ & $0.001 \pm 0.002$ & $0.27 \pm 0.26$ \\
\hline $\begin{array}{l}\text { KRB controls } \\
\quad(n=20)\end{array}$ & $7.15 \pm 0.11$ & $0.16 \pm 0.05$ & $8.47 \pm 3.12$ \\
\hline $\begin{array}{l}\text { KRB amiloride } \\
\quad(n=20)\end{array}$ & $7.14 \pm 0.1$ & $0.12 \pm 0.06$ & $6.16 \pm 2.75$ \\
\hline $\begin{array}{l}\text { KRB DIDS } 0.5 \mathrm{mM} \\
\quad(n=4)\end{array}$ & $6.95 \pm 0.08$ & $0.072 \pm 0.008$ & $3.6 \pm 0.66$ \\
\hline $\begin{array}{l}\text { KRB DIDS } 1 \mathrm{mM} \\
\quad(n=8)\end{array}$ & $6.91 \pm 0.09$ & $0.07 \pm 0.02$ & $3.54 \pm 0.98$ \\
\hline $\begin{array}{l}\text { KRB Cl-depleted } \\
\text { amiloride }(n=4)\end{array}$ & $7.38 \pm 0.07$ & $0.12 \pm 0.003$ & $5.86 \pm 1.22$ \\
\hline
\end{tabular}

For media composition, see Table I. DBE cells were acid loaded by pulse withdrawal of $\mathrm{NH}_{4} \mathrm{Cl}(20 \mathrm{mM}$ in Hepes-buffered media or 30 $\mathrm{mM}$ in media containing bicarbonate; $\mathrm{NH}_{4}$-gluconate substituted $\mathrm{NH}_{4} \mathrm{Cl}$ in $\mathrm{Cl}$-free experiments). Recovery rates were calculated as $\delta \mathrm{pHi} / \mathrm{min}$ during the recovery phase after acidification. $\mathrm{H}^{+}$efflux rates $\left(\mathrm{JH}^{+}\right)$were calcualted from recovery rates and $\beta_{\mathrm{i}}$ as described in the text. (Values are expressed as mean \pm SD.)

Recovery of pHi from an acute acid load. Because intracellular total buffering power increased in $\mathrm{HCO}_{3}^{-}$-containing medium (26), it was necessary to administer $30 \mathrm{mM} \mathrm{NH}_{4} \mathrm{Cl}$ to induce comparable degrees of acidification as observed in $\mathrm{HCO}_{3}^{-}$-free medium (28). As shown in Fig. $6 \mathrm{~A}$, pHi decreased to $6.7 \pm 0.14$ and then recovered to baseline at a significantly higher rate than in the absence of bicarbonate $(8.14 \pm 3.5 \mathrm{mM} /$ $\mathrm{min}$ at $\mathrm{pH} 6.8 \pm 0.06, n=25$ vs. $5.76 \pm 1.78 \mathrm{mM} / \mathrm{min}$ at $\mathrm{pHi}$ $6.78 \pm 0.09, n=14, P<0.01)$.

As shown in Fig. $6 A$, external $\mathrm{Na}^{+}$removal produced a greater degree of acidification $(6.41 \pm 0.19, n=6)$ and, as in the absence of $\mathrm{HCO}_{3}^{-}$, completely blocked pHi recovery $\left(\mathrm{JH}^{+}\right.$ $=0.27 \pm 0.26 \mathrm{mM} / \mathrm{min}, \mathrm{N}=6$ ).

In contrast, as shown in Fig. $6 B$, in the presence of amiloride $(1 \mathrm{mM})$, nadir acidification was lower $(6.6 \pm 0.14, n=20)$, and pHi recovery was only slightly impaired, $\mathrm{JH}^{+}=6.16 \pm 2.75$ $\mathrm{mM} / \mathrm{min}$ at $\mathrm{pHi} 6.77 \pm 0.08, n=20$. Therefore, in the presence of bicarbonate, the amiloride-inhibitable component of pHi recovery amounted to only $27 \%$ of the total recovery rate, versus $62 \%$ in Hepes.

Recovery from an acid load in the presence of amiloride and $\mathrm{HCO}_{3}^{-}$was substantially inhibited by preincubation of BDE cells for $20 \mathrm{~min}$ to $1 \mathrm{~h}$ with $0.5 \mathrm{mM}$ or $1 \mathrm{~mm}$ DIDS (Fig. 7). Nadir pHi was $6.5 \pm 0.11(n=4)$ and $6.53 \pm 0.12(n=8)$,
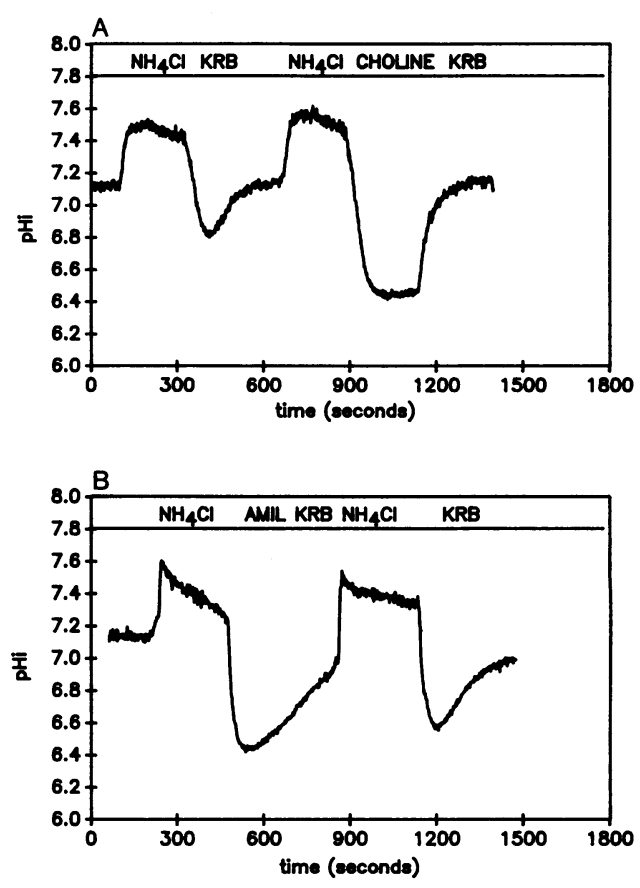

Figure 6. (A) Effect of external $\mathrm{Na}^{+}$removal (equimolar substitution with choline) on pHi recovery from an intracellular acid load, in the presence of $\mathrm{HCO}_{3}^{-}$. Cells were acidified by pulse withdrawal of $30 \mathrm{mM}$ $\mathrm{NH}_{4} \mathrm{Cl}$. pHi recovery was completely inhibited in the absence of $\mathrm{Na}^{+}$ (second pulse) and quickly recovered after $\mathrm{Na}^{+}$readmission. (B) Effect of amiloride on pHi recovery from an acid load in the presence of $\mathrm{HCO}_{3}^{-}$. Amiloride ( $1 \mathrm{mM}$ ) (first pulse), only slightly inhibited $\mathrm{pHi}$ recovery, compared to the control experiment (second pulse). The recording is representative of 20 similar experiments.

respectively, and $\mathrm{JH}^{+}$was reduced to $3.66 \pm 0.66 \mathrm{mM} / \mathrm{min}$ and $3.54 \pm 0.98$, respectively. Acid extrusion rates in the presence of DIDS and amiloride are thus similar to those measured in the absence of $\mathrm{HCO}_{3}^{-}$during amiloride administration, indicating that DIDS specifically inhibited the amiloride-insensitive component of pHi recovery. In addition, the effect of DIDS suggests that this phenomenon is, in part, dependent on $\mathrm{HCO}_{3}^{-}$ transport.

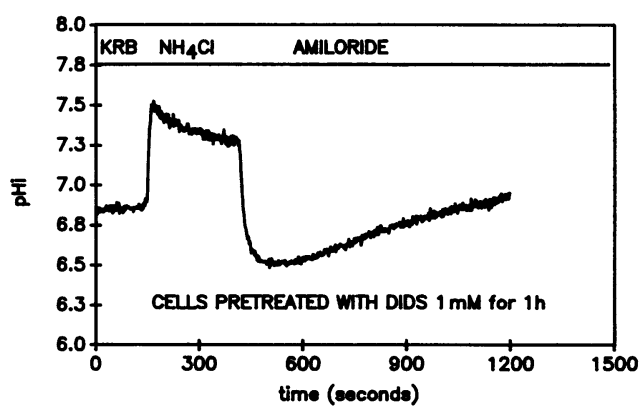

Figure 7. Effect of DIDS on pHi recovery from an acid load in the presence of $\mathrm{HCO}_{3}^{-}$. Cells were preincubated with $1 \mathrm{mM}$ DIDS for 1 $\mathrm{h}$ before acid load. Amiloride $(1 \mathrm{mM})$ was added during the recovery phase to inhibit $\mathrm{Na}^{+} / \mathrm{H}^{+}$-dependent recovery. DIDS greatly inhibited pHi recovery. The tracing is representative of eight similar experiments. Similar results were obtained when cells were preincubated with $0.5 \mathrm{mM}$ DIDS for $20 \mathrm{~min}$. 
Acid extrusion rates were also measured in cells depleted of $\mathrm{Cl}^{-}$by incubating them for $30-40 \mathrm{~min}$ in a $\mathrm{Cl}^{-}$-free medium (equimolar substitution with gluconate). After $\mathrm{Cl}^{-}$removal, basal pHi was significantly higher $(7.38 \pm 0.07, n=4$ vs. $7.14 \pm 0.11$ ) (Table II). After administration and withdrawal of $25 \mathrm{mM} \mathrm{NH}_{4}^{+}$, cells were perfused with $\mathrm{Cl}^{-}$-free $\mathrm{KRB}$ containing $1 \mathrm{mM}$ amiloride. Acid extrusion rates were not significantly different from those measured in the presence of amiloride in $\mathrm{Cl}^{-}$-containing $\mathrm{KRB}(5.84 \pm 1.22$ at pHi $6.94 \pm 0.1, n=4$, vs. $6.16 \pm 2.75, n=20$ ) (Fig. 8). The lack of effect of $\mathrm{Cl}^{-}$depletion on $\mathrm{pHi}$ recovery suggests the involvement of a $\mathrm{Na}^{+}: \mathrm{HCO}_{3}^{-} \mathrm{sym}-$ port rather than a $\mathrm{Na}^{+}$-dependent $\mathrm{Cl}^{-} / \mathrm{HCO}_{3}^{-}$exchange.

Effects of acute $\mathrm{Cl}^{-}$removal. To detect the presence of a $\mathrm{Cl}^{-} / \mathrm{HCO}_{3}^{-}$exchanger, cells were grown in $\alpha$-MEM medium, perfused with bicarbonate containing buffer, and then exposed to acute removal of $\mathrm{Cl}_{\text {out }}^{-}$by substitution with equimolar amounts of gluconate. If an active $\mathrm{Cl}^{-} / \mathrm{HCO}_{3}^{-}$exchanger is present, this maneuver should increase $\mathrm{pHi}$, as $\mathrm{Cl}_{\text {in }}^{-}$is exchanged with $\mathrm{HCO}_{3 \text { out }}^{-}$. As shown in Fig. $9 \mathrm{~A}, \mathrm{Cl}^{-}$removal resulted in a rapid alkalinization of $0.18 \pm 0.008 \mathrm{pHi}$ units, after which $\mathrm{pHi}$ recovered after $\mathrm{Cl}^{-}$readmission $(n=7)$. In cells pretreated with DIDS (Fig. $9 \mathrm{~B}$ ), the rise in pHi during $\mathrm{Cl}^{-}$removal was completely inhibited and pHi decreased by $0.048 \pm 0.035 \mathrm{pHi}$ units $(n=5)$.

\section{Discussion}

In this study, we developed a technique for the isolation of a population of liver nonparenchymal cells enriched in bile ductulär epithelial cells and utilized vital cell markers and microfluorometric procedures to characterize specific ion transport systems that regulate BDE cell intracellular pHi. Our data indicate that these cells possess a Na${ }^{+} / \mathrm{H}^{+}$exchange mechanism that is mainly responsible for pHi regulation in the absence of bicarbonate, mediates recovery from an intracellular acid load and is activated by intracellular acidification. When $\mathrm{HCO}_{3}^{-}$is present, a $\mathrm{Na}^{+}$-dependent, amiloride-insensitive, DIDS-inhibitable, $\mathrm{Cl}^{-}$-independent transport system is also activated (consistent with $\mathrm{Na}^{+}: \mathrm{HCO}_{3}^{-}$symport). This system maintains a higher steady-state $\mathrm{pHi}$ and is involved in the recovery from an intracellular acid load. In addition, the DIDS-inhibitable pHi

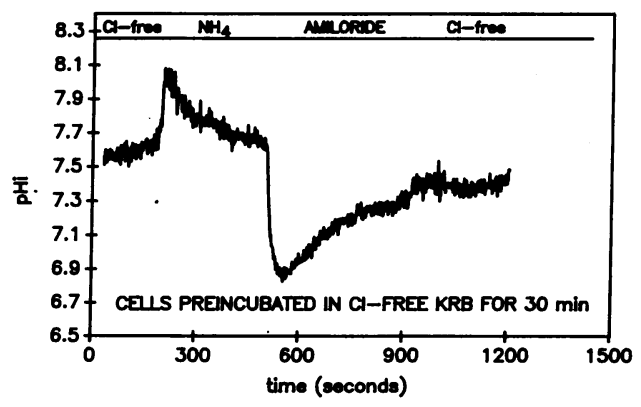

Figure 8. Effects of $\mathrm{Cl}^{-}$depletion on pHi recovery from an acid load in the presence of $\mathrm{HCO}_{3}^{-}$. Cells were preincubated for 30-40 min in $\mathrm{Cl}^{-}$-free $\mathrm{KRB}$ (equimolar substitution with gluconate) and then acid loaded by pulse withdrawal of $25 \mathrm{mM} \mathrm{NH}_{4}$-gluconate. $1 \mathrm{mM}$ amiloride was added during the recovery phase to eliminate the $\mathrm{Na}^{+} / \mathrm{H}^{+}$. dependent component of pHi recovery. $\mathrm{JH}^{+}$measured in these conditions were similar to the one recorded in the presence of normal $\mathrm{Cl}^{-}$concentrations and amiloride.
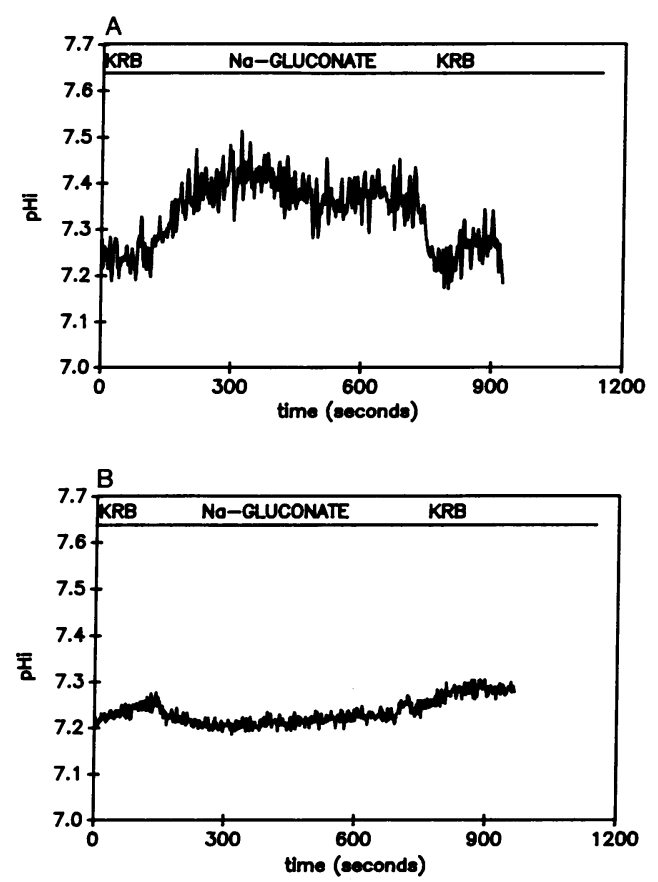

Figure 9. (A) Effects of acute removal of external $\mathrm{Cl}^{-}$(substitution with equimolar gluconate) on baseline pHi in BDE cells (KRB medium). $\mathrm{pHi}$ rapidly alkalinized after $\mathrm{Cl}^{-}$removal and returned to baseline after $\mathrm{Cl}^{-}$readmission. The tracing is representative of seven similar experiments. $(B)$ Baseline $\mathrm{pHi}$ did not alkalinize when the same maneuver was performed in BDE cells preincubated with $1 \mathrm{mM}$ DIDS for $1 \mathrm{~h}$. Data are representative of five similar experiments.

alkalinization induced by acute $\mathrm{Cl}^{-}$removal indicates the presence of a $\mathrm{Cl}^{-} / \mathrm{HCO}_{3}^{-}$exchange, which could act as the acidloading component in the BDE cell pHi regulatory system. These studies indicate that BDE cells, like other epithelia, have the capability of transporting $\mathrm{H}^{+}$and $\mathrm{HCO}_{3}^{-}$and thus might be involved in modifying the electrolyte composition of ductular bile. Future studies will be necessary to determine the membrane polarity of these transporters, their electrophysiological features, and their potential role in biliary electrolyte transport.

Knowledge of the function of BDE cells has been limited because of difficulties in their isolation, related to their small number $(3-5 \%)(2,9)$, compared to other cell populations in the liver, and the similarity in their size and density to other nonparenchymal cell contaminants, including Kupffer, endothelial, and inflammatory cells $(2,29)$. Recently, several techniques have been reported that provided the background upon which our present procedure for isolation of BDE cells is based $(8,9,29)$.

These procedures utilize the known proliferative properties of BDE cells after bile duct ligation, which leads to a selective increase in the number of bile duct cells up to $30-40 \%$ of the hepatic parenchyma mass (type I hyperplasia) $(2,7,8,30)$. Although it is uncertain whether BDE cells isolated from bile duct ligated rats originate from proliferated ductular cells or preexisting hepatocytes, these cells are well differentiated (9), lined by basement membrane-containing laminin (31), and retain phenotypic features of normal BDE cells, including their ultrastructural appearance, GGT staining, and immunoreactivity to cytokeratins 7 and $19(2,8,9,23)$. Thus, it seems likely 
that these cells are phenotypically similar to normal BDE cells and that the transport systems identified in this report approximate normal BDE physiology. These assumptions will, however, need to be validated by developing techniques in the future to isolate BDE cells in sufficient yield from normal animals.

A cell population containing up to $85 \%$ (average, $72 \%$ ) GGT-positive cells was isolated, by combined isopycnic centrifugation in Percoll, centrifugal elutriation, and negative selection by adherence to plastic. These cells were positive for cytokeratins 19 and 7 and showed ultrastructural features of normal BDE cells. The use of vital markers allowed more precise identification of BDE cells, whereas the use of a single-cell microfluorimetric approach enabled reliable recordings of BCECF fluorescence even if the cell yield was low.

Using this approach, a basal pHi of $7.03 \mathrm{pH}$ units was measured in cells incubated in 3\% FCS in the absence of bicarbonate. These values were comparable to most other cells studied (32) but slightly lower than basal pH's observed in hepatic parenchymal cells (21). Difference in concentration of FCS which may activate $\mathrm{Na}^{+}$-proton exchange could account for these differences. Baseline pHi was dependent on extracellular $\mathrm{Na}^{+}$and was decreased by the $\mathrm{Na}^{+} / \mathrm{H}^{+}$exchanger inhibitor amiloride ( 1 $\mathrm{mM}$ ), suggesting that $\mathrm{BDE}$ cell's steady-state $\mathrm{pHi}$ is maintained by a $\mathrm{Na}^{+} / \mathrm{H}^{+}$exchanger that counteracts a background acid loading process (Fig. 2). The presence of an active $\mathrm{Na}^{+}$/proton exchange system in BDE cells was also confirmed by evaluating the effects of $\mathrm{Na}^{+}$removal and amiloride on pHi recovery from an acid load, as discussed in the result section (Fig. $3 A$ and $B$ ). At least $70 \%$ of acid extrusion during $\mathrm{pH}$ recovery from an acid load was mediated by this transporter, as assessed from the effect of amiloride inhibition. As also observed in hepatocytes, part of $\mathrm{H}^{+}$efflux seems to be independent from amiloride inhibition. While this could signal the presence of other mechanisms for $\mathrm{H}^{+}$efflux in addition to $\mathrm{Na}^{+} / \mathrm{H}^{+}$exchange, BDE cells may also be capable of conducting $\mathrm{H}^{+}$across their plasma membranes as observed previously in isolated hepatocytes (21) and hepatocyte membrane vesicles (33). Intracellular acidification usually results in depolarization which would favor $\mathrm{H}^{+}$ extrusion (34). However electrophysiologic approaches will be necessary to evaluate this possibility (35).

When compared to similar data from rat hepatocytes, the BDE cell's $\mathrm{Na}^{+}$proton exchange mechanism is more active. Maximal $\mathrm{H}^{+}$flux rates of $7.45 \mathrm{mM} / \mathrm{min}$ were observed in BDE cells, twice the rate of proton flux observed in this laboratory in subconfluent monolayers of rat hepatocytes (21). This greater activity was also reflected in higher rates of acidification after $\mathrm{Na}^{+}$removal, compared to findings in hepatocytes. As in the other cells, the rate of $\mathrm{Na}^{+} /$proton exchange was inversely proportional to $\mathrm{pHi}$, reflecting the well-known proton-modifying effects on this exchange mechanisms (27). Analysis of Fig. 4 suggests that $\mathrm{BDE}$ cell $\mathrm{Na}^{+} / \mathrm{H}^{+}$exchange is inactive at $\mathrm{pHi}$ values $>7.15$.

In physiological conditions the regulation of $\mathrm{pHi}$ of living animal cells, takes place in the presence of $\mathrm{HCO}_{3}^{-}$. As observed in other cells $(18,21)$, basal pHi was significantly higher when BDE cells were incubated in media containing bicarbonate. Baseline pHi decreased after $\mathrm{Na}^{+}$removal, but was unaffected by amiloride (Fig. 5). On the other hand, when cells were pretreated with DIDS, an inhibitor of $\mathrm{HCO}_{3}^{-}$-dependent transport systems, pHi was lower, and did not differ significantly from values recorded in the absence of bicarbonate. These data sug- gest that in the presence of $\mathrm{HCO}_{3}^{-}$, resting pHi is maintained by a $\mathrm{Na}^{+}$- and $\mathrm{HCO}_{3}^{-}$-dependent but amiloride-insensitive mechanism.

When pHi recovery from an intracellular acid load was measured in the presence of $\mathrm{HCO}_{3}^{-}$, acid extrusion rates were increased $41 \%$ compared to Hepes-buffered media (Fig. 10). In this condition, pHi recovery is mostly mediated by $\mathrm{a} \mathrm{HCO}_{3}^{-}$-dependent mechanism that is completely $\mathrm{Na}^{+}$-dependent, partly inhibited by DIDS and minimally affected by amiloride or by $\mathrm{Cl}^{-}$removal (the amiloride-sensitive component of $\mathrm{pHi}$ recovery being only $27 \%$ of the total recovery rate).

The $\mathrm{Na}^{+}$-dependence excludes mechanisms like $\mathrm{Cl}^{-} / \mathrm{HCO}_{3}^{-}$ exchange and $\mathrm{H}^{+}$(or $\mathrm{OH}^{-}, \mathrm{HCO}_{3}^{-}$) conductances, whereas the inhibition by DIDS confirms that a $\mathrm{HCO}_{3}^{-}$transport system is involved and effectively excludes proton or $\mathrm{H}^{+}-\mathrm{K}^{+}$ATPases. By exclusion, this $\mathrm{HCO}_{3}^{-}$transporter must represent $\mathrm{Na}^{+}$-dependent $\mathrm{Cl}^{-} / \mathrm{HCO}_{3}^{-}$exchange or $\mathrm{Na}^{+}: \mathrm{HCO}_{3}^{-}$symport. However, recovery rates from an acid load in cells that had been depleted of intracellular $\mathrm{Cl}^{-}$were not affected suggesting that the mechanism responsible for acid extrusion is a $\mathrm{Na}^{+}: \mathrm{HCO}_{3}^{-}$ symport.

$\mathrm{Na}^{+}: \mathrm{HCO}_{3}^{-}$symports are usually (renal proximal tubular [36], corneal epithelial [37]) but not always (smooth muscle [38]) electrogenic, transporting (three or two) $\mathrm{HCO}_{3}^{-}$to one $\mathrm{Na}^{+}$. At present it is debated whether rat hepatocyte $\mathrm{Na}^{+}: \mathrm{HCO}_{3}^{-}$is electrogenic $(39,40)$ or not $(21)$, and definitive determination of electrogenicity of the $\mathrm{BDE} \mathrm{HCO}_{3}^{-}$transporter will require electrophysiological measurements of the cell's membrane potential during variations in extracellular $\left[\mathrm{HCO}_{3}^{-}\right]$ (40). If electrogenic, this transporter could function as an acid extruder $\left(\mathrm{HCO}_{3}^{-}\right.$uptake) or loader $\left(\mathrm{HCO}_{3}^{-}\right.$extrusion) depending on the transmembrane electrical potential. Nevertheless, the higher $\mathrm{pHi}$ in the presence of $\mathrm{HCO}_{3}^{-}$and the lower $\mathrm{pHi}$ in cells pretreated with DIDS suggest that the $\mathrm{Na}^{+}: \mathrm{HCO}_{3}^{-}$symport functions as a base loader (acid extruder) in resting conditions as well as following an acid load.

The acute removal of extracellular $\mathrm{Cl}^{-}$resulted in a rise in pHi that was inhibited by pretreatment with DIDS. Although $\mathrm{Cl}^{-}$removal could theoretically produce intracellular alkalinization by causing intracellular depolarization, and thus en-

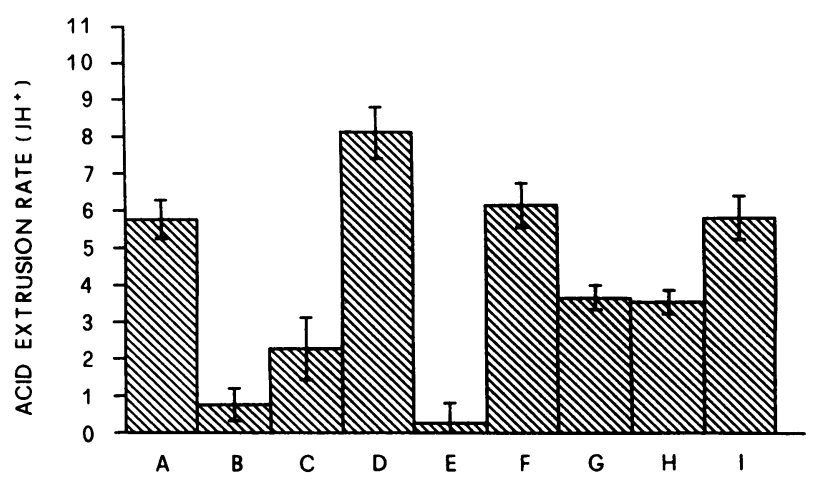

Figure 10. Comparison of measured $\mathrm{H}^{+}$extrusion rates $\left(\mathrm{JH}^{+}\right.$, millimolar/minute) during recovery from an acid load in the absence ( $A$ $C)$ and in the presence $(D-I)$ of $\mathrm{HCO}_{3}^{-} . A$, Hepes controls; $B$, Hepes $\mathrm{Na}^{+}$removal; $C$, Hepes $1 \mathrm{mM}$ amiloride, $D, \mathrm{KRB}$ controls; $E, \mathrm{KRB}$ $\mathrm{Na}^{+}$removal; $F$, KRB $1 \mathrm{mM}$ amiloride; $G, \mathrm{KRB} 0.5 \mathrm{mM}$ DIDS pretreatment $+1 \mathrm{mM}$ amiloride; $H, \mathrm{KRB} 1 \mathrm{mM}$ DIDS $+1 \mathrm{mM}$ amiloride; $I, \mathrm{Cl}^{-}$-free $\mathrm{KRB}+1 \mathrm{mM}$ amiloride. 
hancing an electrogenic $\mathrm{Na}^{+}: \mathrm{HCO}_{3}^{-}$symport, these findings are most consistent with the presence in $\mathrm{BDE}$ cells of $\mathrm{Cl}^{-} / \mathrm{HCO}_{3}^{-}$ exchanger (41). $\mathrm{A} \mathrm{Cl}^{-} / \mathrm{HCO}_{3}^{-}$exchange mechanism has also been identified in canalicular membranes of hepatocytes (42) where it functions as the primary acid loader (bicarbonate extruder) $(22,25)$, as it does in many other cells $(24,43,44)$.

DIDS concentrations used in this study are somewhat higher than ones generally used with other cell types, but are similar to those employed in hepatocytes. Hepatocyte anion transporters are known to be relatively insensitive to DIDS (21, $39,40)$. Moreover, in the isolated perfused rat liver preparation where the integrated function of hepatocytes and ductal system can be evaluated, the liver excretes DIDS into the bile at biliary concentrations up to $5 \mathrm{mM}$ resulting in a decrease in biliary $\mathrm{HCO}_{3}^{-}$concentration that is reversible after DIDS withdrawal (45). Thus, in the intact organ, high DIDS concentrations are tolerated without irreversible inhibition.

Although the present study does not provide information on the localization of the transporters in bile duct epithelial cells, and indeed their polarity might even be altered in BDE cells from bile duct-obstructed animals (46), the battery of ion transporters identified in BDE cells in this study is remarkably similar to the one responsible for transepithelial $\mathrm{HCO}_{3}^{-}$movement in guinea pig gallbladder (47). $\mathrm{Na}^{+}: \mathrm{HCO}_{3}^{-}$symports have been described primarily in epithelial cells involved in electrolyte secretion $(21,28,36,37)$ and their presence in BDE cells, together with active $\mathrm{Na}^{+} / \mathrm{H}^{+}$and $\mathrm{Cl}^{-} / \mathrm{HCO}_{3}^{-}$exchangers, supports the involvement of $\mathrm{BDE}$ cells in transepithelial $\mathrm{H}^{+}$/ $\mathrm{HCO}_{3}^{-}$transport.

Further studies will be necessary in BDE cells isolated from normal animals and maintained in cultures with established epithelial polarity before definitive answers to these questions can be obtained. In the meantime, the approaches developed in the present study should facilitate the development of further information about hepatic bile duct epithelial cell transport systems.

\section{Acknowledgments}

The authors thank Dr. G. Alpini, N. Tavoloni, and A. Sirica for helpful discussions. Dr. Strazzabosco expresses his gratitude to Prof. L. Okolicsanyi and Prof. G. Crepaldi for their constant advice and support.

This work was supported by United States Public Health Service grants DK 34989, 25636, and CA-16359 and by a Yale University Liver Center Pilot Project Grant to Dr. Strazzabosco. Dr. Strazzabosco was a recipient of an International Research Fellowship Award from the J. E. Fogarty Foundation (Public Health Service/National Institutes of Health) No. 1-FO5-TW4061-01.

\section{References}

1. Alpini, G., R. Lenzi, L. Sarkozi, and N. Tavoloni. 1988. Biliary physiology in rats with bile ductular cell hyperplasia. Evidence for a secretory function of proliferated bile ductules. J. Clin. Invest. 81:569-578.

2. Tavoloni, N. 1987. The intrahepatic biliary epithelium: an area of growing interest in hepatology. Semin. Liver Dis. 7:280-292.

3. Tavoloni, N. 1985. Role of ductular bile water reabsorption in canine bile secretion. J. Lab. Clin. Med. 106:154-161.

4. Chenderovitch, J. 1972. Secretory function of a rabbit common bile duct. Am. J. Physiol. 223:695-706.

5. Smith, N. D., and J. L. Boyer. 1982. Permeability characteristics of bile duct in the rat. Am. J. Physiol. 242:G52-G57.
6. Wheeler, E. L., and O. L. Ramos. 1966. Role of bile ducts during secretin choleresis in dogs. Am. J. Physiol. 210:1153-1159.

7. Desmet, V. J. 1987. Cholangiopathies: past, present, and future. Semin. Liver Dis. 7:67-76.

8. Mathis, G. H., S. A. Walls, and A. E. Sirica. 1988. Biochemical characteristics of hyperplastic rat bile ductular epithelial cells cultured "on top" and "inside" different extracellular matrix substitutes. Cancer Res. 48:6145-6153.

9. Alpini, G., R. Lenzi, W.-R. Zhai, M. H. Liu, P. A. Slott, F. Paronetto, and N. Tavoloni. 1989. Isolation of a nonparenchymal liver cell fraction enriched in cells with biliary epithelial phenotypes. Gastroenterology. 97:1248-1260.

10. Rutemberg, A. M., H. Kim, J. W. Fischbein, J. S. Hanker, H. L. Wassenkrug, and A. M. Selingman. 1969. Histochemical and ultrastructural demonstration of gamma-glutamyl transpeptidase activity. J. Histochem. Cytochem. 17:517-526.

11. Jacobs, J. M. J., T. P. Pretlow, N. Fausto, A. Pitts, and T. G. Pretlow. 1981. Separation of two population of cells with gamma-glutamyl transpeptidase from carcinogen-treated rat liver. J. Natl. Cancer Inst. 66:967-973.

12. Sunderland, C. A., W. R. McMaster, and A. F. Williams. 1979. Purification with monoclonal antibodies of a predominant leukocyte common antigen and glycoprotein from rat thymocytes. Eur. J. Immunol. 9:155-159.

13. Irving, M. G., F. J. Roll, S. Huang, and M. Bissel. 1984. Characterization and culture of sinusoidal endothelium from normal rat liver: lipoprotein uptake and collagen phenotype. Gastroenterology. 87:1233-1247.

14. Voyta, J. C., D. P. Via, C. E. Butterfield, and B. R. Zetter. 1984. Identification and isolation of endothelial cells based on their increased uptake of acetylated-low density lipoprotein. J. Cell Biol. 99:2034-2040.

15. Bissel, M., L. Hammaker, and R. Schmid. 1972. Liver sinusoidal cells. Identification of a subpopulation for erythrocyte catabolism. J. Cell Biol. 54:107119.

16. Gautam, A., O. C. Ng, and J. L. Boyer. 1987. Isolated rat hepatocyte couplets in short-term culture: structural characteristics and plasma membrane reorganization. Hepatology (Baltimore). 7:216-223.

17. Strazzabosco, M., S. Sakisaka, T. Hayakawa, and J. L. Boyer. 1991. Effect of UDCA on intracellular and biliary pH in isolated rat hepatocyte couplets and perfused livers. Am. J. Physiol. 260:G58-G29.

18. Boyarsky, G., M. B. Ganz, R. B. Sterzel, and W. F. Boron. 1988. pH regulation in single glomerular mesangial cells. $I$. Acid extrusion in absence and presence of $\mathrm{HCO}_{3}$. Am. J. Physiol. 255:C844-C856.

19. Maher, J. J., M. Bissel, S. L. Friedman, and F. J. Roll. 1988. Collagen measured in primary cultures of normal rat hepatocytes derives from lipocytes within the monolayer. J. Clin. Invest. 82:450-459.

20. Thomas, J. A., R. N. Buchsbaum, A. Zimniak, and E. Racker. 1979. Intracellular pH measurements in Erlich ascites tumor cells utilizing spectroscopic probes generated in situ. Biochemistry. 18:2210-2218.

21. Gleeson, D., N. D. Smith, and J. L. Boyer. 1989. Bicarbonate-dependent and independent intracellular $\mathrm{pH}$ regulatory mechanisms in rat hepatocytes. Evidence for $\mathrm{Na}^{+}: \mathrm{HCO}_{3}^{-}$cotransport. J. Clin. Invest. 84:312-321.

22. Weintraub, W. H., and T. E. Machen. 1989. pH regulation in hepatoma cells: roles for $\mathrm{Na}^{+}-\mathrm{H}^{+}$and $\mathrm{Cl}^{-}-\mathrm{HCO}_{3}^{-}$exchange and for $\mathrm{Na}^{+} / \mathrm{HCO}_{3}^{-}$symport. $\mathrm{Am}$. J. Physiol. 257:G317-G327.

23. Mathis, G. A., S. A. Walls, P. D'Amico, T. E. Gengo, and A. E. Sirica. 1989. Enzyme profile of rat bile ductular epithelial cells in reference to the resistance phenotype in hepatocarcinogenesis. Hepatology (Baltimore). 9:477-485.

24. Wenzl, E., and T. Machen. 1989. Intracellular pH dependency of buffer capacity and anion exchange in the parietal cell. Am. J. Physiol. 257:G741-G747.

25. Benedetti, A., M. Strazzabosco, J. C. Corasanti, P. Haddad, J. Graf, and J. L. Boyer. 1990. Cytoplasmic pH (pHi) recovery from an alkali load in isolated rat hepatocytes is mediated by a $\mathrm{Cl}^{-} / \mathrm{HCO}_{3}^{-}$exchanger. Gastroenterology. 98:A569. (Abstr.)

26. Boron, W. F. 1983. Transport of $\mathrm{H}^{+}$and of ionic weak acids and bases. $J$. Membr. Biol. 72:1-16.

27. Grinstein, S., and A. Rothstein. 1986. Mechanism of regulation of the $\mathrm{Na}^{+} / \mathrm{H}^{+}$exchanger. J. Membr. Biol. 90:1-12.

28. Townsley, M. C., and T. E. Machen. 1989. $\mathrm{Na}^{+}-\mathrm{HCO}_{3}^{-}$cotransport in rabbit parietal cells. Am. J. Physiol. 257:G350-G356.

29. Ishii, M., B. Vroman, and N. F. La Russo. 1989. Isolation and morphologic characterization of bile duct epithelial cells from normal rat liver. Gastroenterology. 97:1236-1247.

30. Alpini, G., R. Lenzi, W.-R. Zhai, P. A. Slott, M. Liu, L. Sarzoki, and N. Tavoloni. 1989. Bile secretory function of intrahepatic biliary epithelium in the rat. Am. J. Physiol. 257:G124-G133.

31. Sirica, A. E., G. A. Mathis, N. Sano, and L. W. Elmore. 1990. Isolation, culture and transplantation of intrahepatic biliary epithelial cells and oval cells. Pathobiol. Annu. 58:44-64.

32. Roos, A., and W. F. Boron. 1981. Intracellular pH. Physiol. Rev. 61:296432.

33. Moseley, R. H., P. J. Meier, P. S. Aronson, and J. L. Boyer. 1986. $\mathrm{Na}^{+} / \mathrm{H}^{+}$ exchange in rat liver basolateral but not canalicular plasma membrane vesicles. Am. J. Physiol. 250:G35-G43.

34. Henderson, R. M., B. Krumpholtz, J. L. Boyer, and J. Graf. 1988. Effect of 
intracellular pH on potassium conductance in liver. Pfluegers Arch. Eur. J. Physiol. 412:334-335.

35. Henderson, R. M., J. Graf, and J. L. Boyer. 1987. $\mathrm{Na}^{+} / \mathrm{H}^{+}$exchange regulates intracellular $\mathrm{pH}$ in isolated rat hepatocyte couplets. Am. J. Physiol. 252:G109-G113.

36. Yoshitomi, K., B.-C. Burckhardt, and E. Froemter. 1985. Rheogenic sodium-bicarbonate cotransport in the peritubular cell membrane of rat renal proximal tubule. Pfluegers. Arch. Eur. J. Physiol. 405:360-366.

37. Jentsch, T. J., S. K. Keller, M. Koch, and M. Wiederholt. 1984. Evidence for coupled transport of bicarbonate and sodium in cultured bovine corneal endothelial cells. J. Membr. Biol. 81:189-204.

38. Aickin, C. C. 1986. Intracellular $\mathrm{pH}$ regulation by vertebrate muscle. Annu. Rev. Physiol. 48:349-361.

39. Renner, E. L., J. R. Lake, B. F. Scharschmidt, B. Zimmerli, and P. J. Meier. 1989. Rat hepatocytes exhibit basolateral $\mathrm{Na}^{+} / \mathrm{HCO}_{3}^{-}$cotransport. J. Clin. Invest. 83:1225-1235.

40. Fitz, J. G., M. Persico, and B. F. Scharschmidt. 1989. Electrophysiological evidences for $\mathrm{Na}^{+}$-coupled bicarbonate transport in cultured rat hepatocytes. $\mathrm{Am}$ J. Physiol. 256:G491-G500.
41. Lowe, A. G., and A. Lanbert. 1983. Chloride-bicarbonate exchange and related transport processes. Biochim. Biophys. Acta. 694:353-374.

42. Meier, P. J., R. G. Knickelbein, R. H. Moseley, J. W. Dobbins, and J. L. Boyer. 1985. Evidence for carrier-mediated chloride/bicarbonate exchange in canalicular rat liver plasma membrane vesicles. J. Clin. Invest. 75:1256-1263.

43. Boyarsky, G., M. B. Ganz, R. B. Sterzel, and W. F. Boron. 1988. pH regulation in single glomerular mesangial cells II. $\mathrm{Na}^{+}$-dependent and -independent $\mathrm{Cl}^{-} / \mathrm{HCO}_{3}^{-}$exchangers. Am. J. Physiol. 255:C857-C869.

44. Stuenkel, E. L., T. E. Machen, and J. A. Williams. 1988. pH regulatory mechanisms in rat pancreatic ductal cells. Am. J. Physiol. 254:G925-G930.

45. Anwer, M. S., K. Nolan, and W. G. M. Hardison. 1988. Role of bicarbonate in biliary excretion of diisothiocyanostilbene disufonate. Am. J. Physiol. 255:G713-G722.

46. Fricker, G., L. Landmann, and P. J. Meier. 1989. Extrahepatic obstructive cholestasis reverses the bile salt secretory polarity of rat hepatocytes. J. Clin. Invest. 84:876-885.

47. Winterhager, J. M., C. P. Stewart, K. Heintze, and K. U. Petersen. 1986. Electroneutral secretion of bicarbonate by guinea pig gallbladder epithelium. Am J. Physiol. 250:C617-C628. 